\title{
A survey of the Elymus L. s. I. species complex (Triticeae, Poaceae) in Italy: taxa and nothotaxa, new combinations and identification key
}

\author{
Enrico Banfi
}

\begin{abstract}
Elymus s. 1. is a critical topic on which only a little light has begun to be made regarding phylogenetic reticulation, genome evolution and consistency of genera. In Italy, Elymus s. 1. officially includes ten species (nine native, one alien) and some well-established and widespread hybrids generally not treated as little or nothing is known of them. In this paper fourteen species (with two subspecies) and six hybrids are taken into account and the following seven new combinations are proposed: Thinopyrum acutum (DC.) Banfi, Thinopyrum corsicum (Hack.) Banfi, Thinopyrum intermedium (Host) Barkworth \& Dewey subsp. pouzolzii (Godr.) Banfi, Thinopyrum obtusiflorum (DC.) Banfi, Thinopyrum $\times$ duvalii (Loret) Banfi, $\times$ Thinoelymus drucei (Stace) Banfi, $\times$ Thinoelymus mucronatus (Opiz) Banfi. Some observations are provided for each subject and a key to species, subspecies and hybrids is made available.
\end{abstract}

Key words: combinations, Elymus, Elytrigia, hybrids, Italy, key, nomenclature, taxonomy, Thinopyrum, $\times$ Thinoelymus.

Riassunto - I recenti progressi della filogenesi in campo genomiale hanno consentito di riproporre la delimitazione di alcuni generi più o meno sommersi in Elymus s. 1. In Italia ad Elymus s. 1. sono ascritte ufficialmente dieci specie (nove autoctone e una alloctona) oltre ad alcuni ibridi stabilizzati e ben diffusi, ma poco considerati in quanto mal conosciuti. In questa sede sono prese in considerazione quattordici specie (con due sottospecie) e sei ibridi, inoltre vengono proposte le seguenti sette nuove combinazioni: Thinopyrum acutum (DC.) Banfi, Thinopyrum corsicum (Hack.) Banfi, Thinopyrum intermedium (Host) Barkworth \& Dewey subsp. pouzolzii (Godr.) Banfi, Thinopyrum obtusiflorum (DC.) Banfi, Thinopyrum $\times$ duvalii (Loret) Banfi, $\times$ Thinoelymus drucei (Stace) Banfi, $\times$ Thinoelymus mucronatus (Opiz) Banfi. Ad ogni entità trattata sono affiancate delle osservazioni e infine si fornisce una chiave per la determinazione di specie, sottospecie e ibridi.

Parole chiave: chiave, combinazioni, Elymus, Elytrigia, ibridi, Italia, nomenclatura, tassonomia, Thinopyrum, $\times$ Thinoelymus.

Sezione di Botanica, Museo di Storia Naturale di Milano, Corso Venezia 55, 20121 Milano, Italia.

E-mail: parajubaea@gmail.com

(C) 2018 Enrico Banfi

Received: 29 January 2018

Accepted for publication: 5 September 2018

\section{INTRODUCTION}

Elymus L. s. 1. is one of the most debated topic among genera within the tribe Triticeae (Poaceae), with representatives spread all over the world. It has been the subject of basic studies (Löve A., 1984; Dewey, 1984) that have opened important horizons not only in the field of agrogenetic research, but also and especially on systematics and taxonomy. However, the still rather coarse knowledge of the genomes and the lack of a satisfactory interpretation of their role in the highly reticulate phylogeny of Triticeae for a long time discouraged taxonomists to clarify species relationships within Elymus s. 1., trying to circumscribe genera consistent on genetic and morphological basis. Subsequently many researchers supported by phylogenetic investigation have solved problems of genome identity succeeding in a more and more better clarification of intergenomial affinities and confirming more and more reliably the genome donors (see for example Chen et al., 1998; Dizkirici et al., 2010; Fan et al., 2013; MasonGamer, 2013; Dong et al., 2015; Gao et al., 2016). For taxonomic purposes, some correlations between genetic arrangement (expressible through genomial formulas) and morphology, ecology and phytogeography have gradually been highlited although much remains to be done. The synthesis of current knowledge is summarized in the taxonomic model adopted by Soreng et al. (2017), where Elymus s. 1. is resolved into five genera [in the haplome acronym, P stands for Agropyron Gaertn., $\mathrm{H}$ for Hordeum L. sect. Stenostachys Nevski, Y possibly for Peridictyon sanctum (Janka) Seberg and W for Australopyrum (Tzvelev) Á.Löve.]: Douglasdeweya C.Yen, J.L.Yang \& B.R.Baum (haplome: StP), Elymus L. [LT: E. sibiricus L.] (=Campeiostachys Drobow, Elytrigia Desv., Hystrix Moench, Roegneria K.Koch, Sitanion Raf.; haplomes: StH, StStH, StHY, StY), Kengyilia C.Yen \& J.L.Yang (haplome: StYP), Pseudoroegneria (Nevski) Á.Löve (haplome: St) and Thinopyrum Á.Löve (haplome: J). On this basis, the European Elymus s. 1. (Melderis, 1980) consists of three genera, Elymus s. s., Pseudoroegneria and Thinopyrum, among which Elymus and Thinopyrum are represented in Italy.

The knowledge of Elymus s. 1. in Italy remained substantially the same for a long time, starting from Fiori (1923), who reported sub "Agropyrum" six species (incl. Agropyron cristatum (L.) Gaertn. subsp. pectinatum 
(M.Bieb.) Tzvelev $=$ A. pectiniforme Roem. \& Schult.), fourteen varieties and two hybrids. Pignatti (1982), adopting again Agropyron, considered a total of ten species and two hybrids; finally Pignatti (2017), recovering Elymus and keeping apart A. pectiniforme, takes into account nine species, three subspecies and four hybrids. The current treatment is reported in the checklist of the Italian flora (Bartolucci et al., 2018; Galasso et al., 2018). No doubt, the major troubles in systematics and taxonomy of Italian Elymus are derived largely from the strong diversity of Elymus repens and its gene flow relationships with Thinopyrum species, still overall difficult to interpret and so far only partially resolved. In this regard, the most influenced morphological characters are the glaucescence, the profile, thickness and sequence of ribs on the adaxial blade surface, the morphology of glumes and lemmas and the hairiness. Hohla \& Scholz (2011) have investigated some Austrian Elytrigia populations concluding with the description of two species, Elytrigia aeneana and $E$. laxula, recognized by these authors as separated from the sympatric Elytrigia repens (= Elymus repens) and E. atherica (= Thinopyrum acutum, see below) and believed to be endemic to Austria. Unfortunately, nothing is known about ploidy level and genome, however, because of pollen sterility documented by the same authors, E. aeneana and E. laxula are likely to fall into the hybrid complex of Elymus campestris, E. repens and Thinopyrum acutum, shared by most of the populations from Europe, including Italy. Such phenotypes, for example, can be observed in France (Tison \& de Foucault, 2014), where thrive both Elymus campestris subsp. campestris and E. c. subsp. maritimus (Tzvelev) Lambinon, the first one known as the parental of hybrids with Elymus repens and Thinopyrum intermedium. In Italy $E$. campestris subsp. campestris was erroneously reported by Fiori (1923) as a synonym of Agropyron repens (L.) P.Beauv. var. arenosum (Spenner) Fiori (三Elymus arenosus (Spenner) Conert), generating a double issue since 1) the synonymy is mistaken, 2) the distributional area of E. arenosus is limited to northern Atlantic Europe. Nevertheless, as we will see later, there are concrete indications of the occurrence of Elymus campestris in Italy and at least of its hybrid with Elymus repens. Anyway, it is necessary to conclude by reiterating that at least two hybrids are relevantly widespread in Italy, since they behave like perfectly autonomous nothospecies which bypass the sterility barrier by a very efficient vegetative propagation, imposing themselves on open vegetations over significant extensions. Without checking male sterility, these nothospecies are regularly mistaken for their parental species, that is Elymus repens (glaucous versions) and Thinopyrum acutum, as frequently reported in the floras.

\section{MATERIALS AND METHODS}

To approach somewhat critical material, specimens have been examined which belong to collections of Liguria (MSNM), Lombardy (PAV), Tuscany (SI) and Puglia (MSNM). By means of a binocular microscope Wild Heerbrugg MB, the specimens' sterility was investigated in relation to the development of pre- and post-anthetic anthers, the quantity and quality of the pollen and the presence of normally developed caryopses in late season collected specimens. Furthermore, the morphology of the leaf adaxial surface was taken into account, especially regarding the kind of ribs (thickness and profile), their succession from margin to margin on blade surface and the presence of trichomes such as spinules, short hairs, long hairs. Cilia and spinules have also been checked on the edges of the rachis and rachilla segments as well as on margins and keels of glumes, lemmas and paleas together with free margins and surface of the sheath. A particular kind of spinules called papillae, provided with a bulbous base with an aculeate apex facing forward (antrorse) recalling the sting of a scorpion, has been investigated on the adaxial, concave surface of the glumes as an important diagnostic character. Finally, dimensional characters of the synflorescence, spikelet and flower, together with features of the vegetative shoots, culm bases and rhizomes, have also been taken into consideration.

\section{TAXA AND NOTHOTAXA TREATED, NEW COMBINATIONS}

According to the checklist of both native and alien Italian flora (Bartolucci et al., 2018; Galasso et al. 2018), Elymus s. 1. (excl. Agropyron) in Italy is represented by ten species, nine of which native and one alien $(E . o b-$ tusiflorus); there are three subspecies, one of which ( $E$. hispidus subsp. pouzolzii) is indicated as possibly present, but until now not confirmed. The Italian (regional) distribution for each taxon is reported with further information in the aforementioned checklists. In the present treatment, six species, that for some reasons concern the Italian flora, have also been taken into account. Furthermore I have considered three nothotaxa and three unnamed hybrids, both actually and potentially widespread in Italy, which are poorly known, possibly confused with the parental species and only marginally mentioned in the floras. I did not take into consideration the genus Agropyron since it appears sufficiently separated from Elymus s.l., to which is related only as genome donor.

Because of the aforementioned correlation existing between phenotypes and modernly revised genomes taken as a criterion for delimiting and recognizing the genera, there is a need to update the nomenclature for four taxa and three nothotaxa representative of the Italian flora. This occasion also requires the establishment of the new nothogenus $\times$ Thinoelymus for hybrids Thinopyrum $\times$ Ely$m u s$, except for one of them, currently unnamed, the type of which at the moment cannot be designated and for two cases in which the genome of one of the parental species (Elymus campestris) is still unknown. Ultimately, seven new combinations are proposed here.

Elymus campestris (Godr. \& Gren.) Kerguélen subsp. campestris (三 Agropyron campestre Godr. \& Gren. $\equiv$ Elytrigia campestris (Godr. \& Gren.) M.A.Carreras $\equiv$ Elymus pungens (Pers.) Melderis subsp. campestris (Godr. \& Gren.) Melderis $\equiv$ Elytrigia pungens (Pers.) Tutin subsp. campestris (Godr. \& Gren.) Á.Löve). $2 \mathrm{n}=56(?)$, genome unknown. 
The placement of Agropyron campestre in the genus Elymus remains provisional until its genome will be sufficiently known. The species consists of two subspecies: the nominal one and the subsp. maritimus (Tzvelev) Lambinon, growing along the North Sea and Channel coasts. Subsp. campestris, common in France, has never been reported from Italy while it is considered possibly present in Poland (Mizianty et al., 2001) and has been confirmed in Croatia, Istria and the isle of Cres by Rottensteiner (2014:717, 2017:227). Recently the writer had the opportunity to examine Italian collections from Liguria, Lombardy and Tuscany: all the specimens showed glumes more or less densely sprinkled with pointed papillae facing forward (antrorse) on the adaxial surface. This character, according to Tison $\&$ de Foucault (2014), is diagnostic for the species. It is worth noting that there were few individuals with anthers bearing normally developed pollen grains, while the majority showed a predominant proportion of sterile ones or no grains at all, betraying a hybrid origin. Therefore it must be concluded that in Italy there are both $E$. campestris and its most probable hybrid, that one with E. repens. Living material possibly attributable to this hybrid is currently being studied for cytology; it comes from Liguria and Lombardy, the second provenance already reported by Ardenghi \& Polani (2016) in a note to Elymus repens for the flora of the province of Pavia. Furthermore, the presence of E. campestris $\times$ Thinopyrum intermedium subsp. intermedium is also likely, this hybrid being already known in France where it is not infrequent. For this reason I think necessary to add to the identification key (see further) this species with related hybrids.

Elymus caninus (L.) L. (三 Triticum caninum L. $\equiv$ Agropyron caninum (L.) P.Beauv. $\equiv$ Goulardia canina (L.) Husn. $\equiv$ Roegneria canina (L.) Nevski) (= Triticum biflorum Brign. $\equiv$ Elymus caninus subsp. biflorus (Brign.) Á.Löve \& D.Löve). 2n=28, haplome: StY.

This species belongs to Elymus sect. Goulardia (Husn.) Tzvelev.

Elymus panormitanus (Parl.) Tzvelev (三 Agropyron panormitanum Parl. $\equiv$ Roegneria panormitana (Parl.) Nevski). 2n=28, haplome: StY.

This species belongs to Elymus sect. Goulardia (Husn.) Tzvelev.

Elymus repens (L.) Gould (三 Triticum repens L. $\equiv$ Agropyron repens (L.) P.Beauv. $\equiv$ Elytrigia repens (L.) Nevski). $2 \mathrm{n}=42$, haplome: $\mathrm{StStH}$.

This species is the type-species of Elymus sect. Elytrigia (Desv.) Melderis. It is unanimously assumed to be a highly polymorphic taxon that encompasses numerous infrataxa described at subspecies, variety and form rank. Part of such diversity has been resolved in recognizing distinct species, often recovered in rank from the intraspecific pool of E. repens, as is the case of the already cited subsp. arenosus ("Petif") Melderis, appropriately recombined at species rank under Elymus arenosus (Spenner) Conert or Elytrigia arenosa (Spenner) H.Scholz. Anyway, the lectotype of Elymus repens (LINN 104.7) as designated by Bowden (1965) corresponds to the green (not glaucous) phenotype bearing spikelets with lemmas very shortly awned, feature which does not resolve the remaining diversity, but helps to fix a morphological point of reference.

Elytrigia aenaeana Hohla \& H.Scholz (= Agropyron campestre auct. nonnulli, non Godr. \& Gren.). 2n=?, genome: unknown.

Elytrigia laxula Hohla \& H.Scholz (= Triticum acutum auct. nonnulli, non DC.). $2 \mathrm{n}=$ ?, genome: unknown.

These two species have been described for Austria (Hohla \& Scholz, 2011), where they form populations growing mainly on sandy soils in various, open habitats along the rivers Inn, Salzach and Donau. Updating the genus for both species is not practicable in the absence of knowledge about their genome, therefore they must be temporarily kept under the original binomials. Although E. aenaeana and E. laxula are considered by their authors endemic to Austria, the last word on their distribution cannot be said, especially considering the long-lasting confusion that persisted between these species on one side and the unresolved glaucous phenotypes of Elymus repens together with Thinopyrum acutum and the hybrids of Elymus campestris on the other. Anyway also these two taxa are added to the key for Italian species, given the possibility that they share a range wider than previously assumed.

Thinopyrum acutum (DC.) Banfi, comb. nov. Bas.: Triticum acutum DC., Cat. Pl. Horti Monsp.: 153. 1813 [Feb-Mar 1813]. (三 Agropyron acutum (DC.) Roem.\& Schult. $\equiv$ Elymus acutus (DC.) M.-A. Thiébaud $\equiv$ Elytrigia acuta (DC.) Tzvelev (pro hybr.) (= Triticum athericum Link $\equiv$ Elymus athericus (Link) Kerguélen $\equiv$ Elytrigia atherica (Link) M.A.Carreras) (= Triticum pycnanthum Godr. $\equiv$ Elymus pycnanthus (Godr.) Melderis $\equiv$ Elytrigia pycnantha (Godr.) Á.Löve $\equiv$ Thinopyrum pycnanthum (Godr.) Barkworth). 2n=42, haplome: J StP.

Since Thiébaud (1987), the epithet acutum was erroneously applied to the supposed hybrid between this species and Thinopyrum junceum (L.) Á.Löve, until Tison \& de Foucault (2014) pointed out that the type specimen of Triticum acutum exactly fits the species in question. Consequently, the epithet of De Candolle has priority over all others.

Thinopyrum corsicum (Hack.) Banfi, comb. nov. Bas.: Agropyron caespitosum K.Koch var. corsicum Hack., in Briquet J., Prodr. Fl. Cors. 1: 187. 1910. (三 Agropyron corsicum (Hack.) Rouy $\equiv$ Elymus corsicus (Hack.) Kerguélen $\equiv$ Elytrigia corsica (Hack.) Holub $\equiv$ Elymus nodosus (Nevski) Melderis subsp. corsicus (Hack.) Melderis). $2 \mathrm{n}=28$, haplome: $\mathrm{J}_{1} \mathrm{~J}_{1}$.

Strictly speaking this species does not belong to the Italian flora, however here it has been taken into account as it was traditionally included in the national treatments.

Thinopyrum elongatum (Host) D.R.Dewey (三 Triticum elongatum Host $\equiv$ Elymus elongatus (Host) Runemark $\equiv$ Elytrigia elongata (Host) Nevski $\equiv$ Lophopyrum elongatum (Host) Á.Löve) (= Agropyron scirpeum C.Presl var. scirpeum). $2 \mathrm{n}=14$, haplome: $\mathrm{J}_{1}$.

Thinopyrum flaccidifolium (Boiss. \& Heldr.) Moustakas (三Agropyron scirpeum C.Presl var. flaccidifolium Boiss. \& Heldr. $\equiv$ Elymus flaccidifolius (Boiss.\& Hel- 
dr.) Melderis $\equiv$ Elytrigia flaccidifolia (Boiss.\& Heldr.) Holub $\equiv$ Lophopyrum flaccidifolium (Boiss.\& Heldr.) Á.Löve) (= Elytrigia scirpea sensu Holub, not Agropyron scirpeum C.Presl var. scirpeum $\equiv$ Lophopyrum scirpeum sensu Á.Löve, not Agropyron scirpeum C.Presl var. scirpeum $\equiv$ Elymus scirpeus sensu Arrigoni, not Agropyron scirpeum C.Presl var. scirpeum). 2n=28, haplome: $\mathrm{J}_{1} \mathrm{~J}_{2}$.

This species, described from Greece, was already known in Italy from Sicily and recently has been reported from Sardinia (Arrigoni, 2015: 295). It has been and still is subject to nomenclatural confusion due to the exchange of types between Agropyron scirpeum var. scirpeum and A. s. var. flaccidifolium. To this regard, the protologue of var. flaccidifolium by Boissier \& Heldreich (1859) states: "Folia radicalia [....] facie superiori breviter et patule hirsuta", to be intended as a character distinctive from the nominal variety of the species. T. elongatum, in fact, shows scattered spinules on the adaxial blade surface of basal leaves, sometimes accompanied by short setae not at all comparable with the tomentum of short hairs typical of T. flaccidifolium.

Thinopyrum junceum (L.) Á.Löve (三 Triticum junceum L. $\equiv$ Braconotia juncea $(\mathrm{L}$.) Godr. $\equiv$ Festuca juncea (L.) Moench $\equiv$ Frumentum junceum (L.) E.H.L.Krause $\equiv$ Elytrigia juncea (L.) Nevski) (= Triticum farctum Viv. $\equiv$ Elymus farctus (Viv.) Runemark ex Melderis subsp. farctus) (= Agropyron junceum (L.) P.Beauv. subsp. mediterraneum Simonet) (= Thinopyrum runemarkii Á.Löve). $2 \mathrm{n}=42$, haplome: $\mathrm{J}_{1} \mathrm{~J}_{2} \mathrm{~J}_{3}$.

As already mentioned, this species of the beaches, nominal for the Mediterranean phytosociological alliance Agropyrion juncei (Tüxen in Br.-Bl. \& Tüxen 1952) Géhu et al. 1984, is vicariated on the Atlantic European coasts by $T$. junceiforme $(2 \mathrm{n}=28$, haplome: J1J2) in the alliance Ammophilion arenariae (Tüxen in Br.-Bl. \& Tüxen 1952) Géhu 1988.

Thinopyrum podperae (Nábělek) D.R.Dewey (三 Agropyron podperae Nábělek $\equiv$ Elymus hispidus subsp. podperae (Nábělek) Melderis $\equiv$ Elymus hispidus var. podperae (Nábělek) Assadi $\equiv$ Elytrigia podperae (Nábělek) Holub $\equiv$ Elytrigia intermedia subsp. podperae (Nábělek) Á.Löve) . 2n=42, haplome: J J $\mathrm{J}_{2} \mathrm{P}$.

Thinopyrum sartorii (Boiss. \& Heldr.) Á.Löve (三 Agropyron junceum var. sartorii Boiss. \& Heldr.) (= Agropyron rechingeri Runemark $=$ Elymus rechingeri (Runemark) Runemark $=$ Elymus farctus subsp. rechingeri (Runemark) Melderis). $2 \mathrm{n}=28$, haplome: $\mathrm{J}_{1} \mathrm{~J}_{2}$.

The presence in Italy of $T$. podperae (Iran, Iraq, Turkey) and T. sartorii (Aegean region) is quite surprising, especially for the first one. It can indirectly be deduced from the table 1 in the paper of Baum \& Johnson (2017), where authors include Italy among territories interested by the range of these species. If this report is correct, I do not know the origin of such information, but the fact remains that until now there is no evidence of these species neither from field observations nor from herbarium material. Pignatti (2017) in a note to T. junceum (under Elymus farctus) suggests the possible presence in Italy of Thinopyrum bessarabicum (Săvul. \& Rayss) Á.Löve (Black Sea coasts) to explain the presence of caespitose individuals occasionally meeting in normally rhizomatous populations. It would perhaps be more likely to think that this unusual habit can be expected within the extremes of diversity of $T$. junceum.

Thinopyrum intermedium (Host) Barkworth \& D.R.Dewey subsp. intermedium ( $\equiv$ Triticum intermedium Host $\equiv$ Agropyron glaucum var. intermedium (Host) Beck $\equiv$ Elytrigia intermedia (Host) Nevski $\equiv$ Trichopyrum intermedium (Host) Á.Löve) (= Agropyron hispidum Opiz $\equiv$ Elymus hispidus (Opiz) Melderis). 2n=42, haplome: $\mathrm{J}_{1} \mathrm{~J}_{2} \mathrm{P}$.

The nominal subspecies represents the commonest lineage in Italy.

Thinopyrum intermedium (Host) Barkworth \& D.R.Dewey subsp. barbulatum (Schur) Barkworth e D.R.Dewey (三Agropyron barbulatum Schur $\equiv$ Agropyron glaucum subsp. barbulatum (Schur) K.Richt. $\equiv$ Agropyron glaucum var. barbulatum (Schur) K.Richt. $\equiv$ Agropyron trichophorum f. barbulatum (Schur) Anghel \& Morariu $\equiv$ Elymus hispidus subsp. barbulatus (Schur) Melderis $\equiv$ Elytrigia intermedia subsp. barbulata (Schur) Á.Löve $\equiv$ Trichopyrum intermedium subsp. barbulatum (Schur) Á.Löve) (= Triticum trichophorum Link $\equiv$ Agropyron trichophorum (Link) K.Richt. =Agropyron glaucum var. trichophorum (Link) Beck $\equiv$ Agropyron intermedium subsp. trichophorum (Link) Asch. \& Graebn. $\equiv$ Agropyron intermedium var. trichophorum (Link) Halácsy $\equiv$ Agropyron truncatum subsp. trichophorum (Link) Soó $\equiv$ Elytrigia trichophora (Link) Nevski E Elytrigia intermedia subsp. trichophora (Link) Á.Löve \& D.Löve). $2 \mathrm{n}=42$, haplome: $\mathrm{J}_{1} \mathrm{~J}_{2} \mathrm{P}$.

Very localized in Italy.

Thinopyrum intermedium (Host) Barkworth \& D.R.Dewey subsp. pouzolzii (Godr.) Banfi, comb. nov. Bas.: Triticum pouzolzii Godr., Mém. Soc. Emul. Doubs Ser. 2, 5 (1854): 11. 1854. (三Elymus hispidus (Opiz) Melderis subsp. pouzolzii (Godr.) Melderis $\equiv$ Elytrigia intermedia (Host) Nevski subsp. pouzolzii (Godr.) M.A.Carreras $\equiv$ Trichopyrum intermedium (Host) Á.Löve subsp. pouzolzii (Godr.) Á.Löve) (= Triticum latronum Godr. $=$ Agropyron latronum (Godr.) P.Candargy). $2 \mathrm{n}=42$, haplome: $\mathrm{J}_{1} \mathrm{~J}_{2} \mathrm{P}$.

Until now not observed or possibly mistaken for impoverished forms of subsp. intermedium. Its presence, at least in the continental sector of extreme North West Italy, is very likely.

Thinopyrum obtusiflorum (DC.) Banfi, comb. nov. Bas.: Triticum obtusiflorum DC., Cat. Pl. Horti Monsp.: 153. 1813. (三Elymus obtusiflorus (DC.) Conert $\equiv$ Elytrigia obtusiflora (DC.) Tzvelev) (= Triticum ponticum Podp. $\equiv$ Elymus ponticus (Podp.) N.Snow $\equiv$ Elymus elongatus (Host) Runemark subsp. ponticus (Podp.) Melderis $\equiv$ Elytrigia pontica (Podp.) Holub $\equiv$ Lophopyrum ponticum (Podp.) Á.Löve $\equiv$ Thinopyrum ponticum (Podp.) Barkworth \& D.R.Dewey). $2 \mathrm{n}=70$, haplome: JJJJ J .

The epithet obtusiflorum has priority on ponticum. Valdés \& Scholz (2006) in the Euro+Med treatment consider this species as native to Italy, however its primary range concerns the European and Near Asian 
East with occasional occurrences in France and Italy, events that can be explained as a secondary introduction (Barchieri \& Ardenghi, 2013; Tison \& de Foucault, 2014; Pignatti, 2017). On the other hand, Jarvie (1992) already questioned the indigenate of this species regarding France and Italy, so Galasso et al. (2018) correctly implemented it in the checklist of the Italian alien species.

Thinopyrum $\times$ duvalii (Loret) Banfi, comb. nov. Bas.: Triticum $\times$ duvalii Loret, in Loret H. \& Barrandon A., Fl. Montpellier ed. 2: 575. 1886., in adnot. (EAgropyron $\times$ duvalii (Loret) P.Candargy $\equiv$ Elytrigia $\times$ duvalii (Loret) Tzvelev) (=Elymus $\times$ acutus sensu Thiébaud $\equiv$ Elytrigia $\times$ acuta sensu Tzvelev, sensu Kerguélen and sensu Stace) (T. acutum $\times$ junceum). $2 \mathrm{n}=42$, genome: $\mathrm{J}_{1} \mathrm{~J}_{\mathrm{J}_{2}} \mathrm{~J}_{3} \mathrm{StP}$.

According to some authors (e.g. Stace, 2001; Tison \& de Foucault, 2014), the parental species Elytrigia juncea (= Thinopyrum junceum) consists of two intraspecific taxa: the Mediterranean subsp. juncea and the North Atlantic subsp. boreoatlantica (Simonet \& Guin.) Hyl. (三 Agropyron junceum subsp. boreali-atlanticum Simonet \& Guin.), so their respective hybrids with $T$. acutum must be treated as nothosubspecies of the same nothospecies. The epithet of this one must be chosen between the available names duvalii and obtusiusculum, depending on types identity and priority, but this is not our case. In fact, starting from a different point of view, I agree with authors who believe that juncea and boreoatlantica are distinct species to be named respectively Thinopyrum junceum (L.) Á.Löve and Thinopyrum junceiforme (Á.Löve \& D.Löve) Á.Löve on the basis of a clearly different morphology, ploidy level (6x versus 4x) and geography. Stace (2001) demonstrated that Agropyron $\times$ obtusiusculum Lange, described for the North Atlantic region, has T. junceiforme as parental species while Triticum $\times$ duvalii $(=$ Elytrigia $\times$ acuta sensu Stace), described for the coast of Montpellier (Mediterranean France), has T. junceum as parental species. It follows that the Italian hybrid population certainly must be referred to $T$. $\times$ duvalii.

$\times$ Thinoelymus drucei (Stace) Banfi, comb. nov. Bas.: Elytrigia $\times$ drucei Stace, Watsonia 23(4): 546. 2001. (三 Elymus $\times$ drucei (Stace) Lambinon) (= Elymus $\times$ oliveri auct., non Agropyron oliveri Druce) (Thinopyrum acutum $\times$ Elymus repens). $2 \mathrm{n}=42$, genome: $\mathrm{J}$ StStStHP.

As anticipated above, I propose here the nothogenus $\times$ Thinoelymus for hybrids between Thinopyrum and Elymus. T. $\times$ druce $i$ was long reported under the epithet oliveri that Druce (1914) began to apply to the material sent to Hackel (Thinopyrum acutum $\times$ Elymus repens), without having previously specified the taxon identity in his original collection (Blakeney, Norfolk, England). Stace (2001) demonstrated that the type specimen (OXF), labelled by its author as Agropyron pungens [= Thinopyrum acutum ] $\times$ repens, actually is the hybrid Thinopyrum junceiforme $\times$ Elymus repens, known as Triticum $\times$ laxum Fr. (pro sp.) whose presence in the Mediterranean area is unlikely.

According to Pignatti (2017), this nothospecies is widespread in northern and central Italy, especially along the coasts. However, due to the very likely coexistence of the hybrid Elymus campestris $\times$ repens, easily mistakable with $\times T$. drucei, it is prudent to avoid hasty conclusions.

$\times$ Thinoelymus mucronatus (Opiz) Banfi, comb. nov. Bas.: Agropyrum mucronatum Opiz, Naturalientausch 6: 42. 1824 [29 Jan 1824]. (三Elymus $\times$ mucronatus (Opiz) Conert $\equiv$ Elytrigia $\times$ mucronata $(\mathrm{Opiz})$ Prokudin $\equiv$ Elytrigia intermedia (Host) Nevski subsp. mucronata ("Bercht.") Valdés \& H.Scholz (Thinopyrum intermedium $\times$ Elymus repens). $2 \mathrm{n}=42$, genome: $\mathrm{J}_{1} \mathrm{~J}_{2}$ StStHP.

Because of the intraspecific diversity of Thinopyrum intermedium, at the moment it is impossible to define the nothosubspecies for this hybrid.

\section{Aknowledgements}

The author is grateful to Prof. Gianniantonio Domina (University of Palermo) for having made available some essential bibliography. He is also grateful to $\mathrm{Dr}$. $\mathrm{PhD} \mathrm{Ni-}$ cola M. G. Ardenghi (University of Pavia) for providing important information about Elymus and Thinopyrum in the province of Pavia.

\section{KEY TO SPECIES, SUBSPECIES AND HYBRIDS}

1 Synflorescence soft, easily flexible; glumes and lemmas papery, the first ones progressively aculeolate on ribs towards the apex, the second with a thin, sometimes a bit flexuous apical awn .................... 2

- Synflorescence more or less rigid, scarcely flexible; glumes and lemmas subcoriaceous, the first ones aculeolate just on the keel, the second unawned, mucronate or with a thick, straight apical awn ..... 3

2 Glumes shorter then the first lemma, ribs spaced ....... Elymus caninus

- Glumes at least as long as the first lemma, ribs crowded Elymus panormitanus

3 Anthers in bud turgid, regularly dehiscent; pollen with grains subequal, mostly well developed and viable (never vitreous); caryopses regularly formed

- Anthers somewhat flat and flaccid in bud, hardly dehiscent; pollen grains scarce or lacking, unequal, very irregular, often empty and vitreous; the caryopses do not form ................................................ 16

4 Rhizomes absent, culms in well delimited tufts ...... 5

- Rhizomes more or less developed, culms sparse or in loose, often undefined tufts ........................... 9

5 Adaxial blade surface finely velvety-tomentose with hairs $<0.3 \mathrm{~mm}$; blades not wider than $2 \mathrm{~mm}$ 6

- Adaxial blade surface spinulose, glabrous or sparsely hairy (hairs $>0.3 \mathrm{~mm}$ ), never velvety-tomentose; blades to $5 \mathrm{~mm}$ wide ........................................ 8

6 Rachis fragile, self-disarticulating at maturity ......... Thinopyrum sartorii

- Rachis robust, not disarticulating at maturity .......... 7

7 Culms (incl. sheaths) between $2^{\text {nd }}$ and $4^{\text {th }}$ node mainly not more than $1.5 \mathrm{~mm}$ thick; spikelets usually not or little compressed 
- Culms (incl. sheaths) between $2^{\text {nd }}$ and $4^{\text {th }}$ node mainly not less than $2.5 \mathrm{~mm}$ thick; spikelets usually compressed

Thinopyrum flaccidifolium

8 Rachilla segments almost smooth on the edges; lemmas mainly 7-veined; spikelets $10-17 \mathrm{~mm}$ with 7-8 flowers

Thinopyrum elongatum

- Rachilla segments on the edges with papillae; lemmas mainly 3-5-veined; spikelets $17-25 \mathrm{~mm}$ with 8-13 flowers ................ Thinopyrum obtusiflorum

9 Adaxial blade surface finely velvety-tomentose by hairs $<0.3 \mathrm{~mm}$; rachis fragile, self-disarticulating at maturity, with smooth edges

Thinopyrum junceum Adaxial blade surface glabrous to sparsely hairy with hairs $>0.5 \mathrm{~mm}$; rachis robust, not disarticulating at maturity, denticulate with papillae on the edges ......... 10

10 Mature spikelets with flowers loosely imbricate, the $2^{\text {nd }}$ rachilla segment $\geq 20 \%$ of the adjacent lemma; glumes (excluding apical mucro or awn) obtuse to obliquely truncated 11 Mature spikelets with flowers thickly imbricate, the $2^{\text {nd }}$ rachilla segment $\leq 20 \%$ of the adjacent lemma; glumes (excluding apical mucro or awn) acute to obtuse .................................. 14

11 Spikelets mainly with 4-5 flowers, scarcely appressed to the rachis to erecto-patent ...................... 12

12 Glumes and lemmas ciliate at the margins only . Thinopyrum podperae Glumes and lemmas ciliate everywhere or glabrous .......................................................... 13

13 Glumes and lemmas hairless ....

Thinopyrum intermedium subsp. intermedium Glumes and lemmas hairy

...... Thinopyrum intermedium subsp. barbulatum

14 Adaxial blade surface on average with 1 prominent rib every 4; glumes (excluding mucro or awn) acute; leaves and culms green to glaucous Elymus repens

Adaxial blade surface on average with 1 prominent rib every 2 or with all ribs prominent; glumes (excluding mucro or awn) subobtuse to obtuse (acute in Thinopyrum acutum); leaves and culms always glaucous-green to glaucous 15

15 Adaxial surface of the glumes without papillae (smooth); lemma (excluding mucro or awn) usually not more than $0.5 \mathrm{~mm}$ exceeding the palea; adaxial blade surface with all or almost all ribs prominent; plants growing along the coasts, less frequently far from the sea

Thinopyrum acutum

Adaxial surface of the glumes coated with papillae; lemma (excluding mucro or awn) usually exceeding the palea for at least $0.5 \mathrm{~mm}$; adaxial blade surface with alternation of prominent and thin ribs; plants usually growing away from beaches

Elymus campestris subsp. campestris

16 Adaxial blade surface more or less densely velvety by hairs $<0.5 \mathrm{~mm}$; rachis edges smooth or bearing more or less sparse, minute papillae which are deciduous under flexion of the mature synflo- rescence; glumes and lemmas on average 11-14 mm long; coastal plants ................................. 17

- Adaxial blade surface glabrous or with sparse hairs $>$ $0.5 \mathrm{~mm}$; edges of the rachis denticulate with minute papillae not deciduous under flexion of the mature synflorescence; glumes and lemmas 6-12 mm long; coastal and inner land plants ........................... 18

17 Adaxial blade surface with subequal ribs .......... Thinopyrum $\times$ duvalii Adaxial blade surface with clearly unequal ribs Thinopyrum junceum $\times$ Elymus repens

18 Glumes (excluding mucro or awn) evidently obtuse; flowers of mature spikelets loosely imbricate, the $2^{\text {nd }}$ rachilla segment $\geq 20 \%$ of the adjacent lemma .................................................. 19

- Glumes (excluding mucro or awn) subacute to acute at least in proximal spikelets; mature spikelets with flower thickly imbricated, the $2^{\text {nd }}$ rachilla segment $\leq 20 \%$ of the adjacent lemma ..................... 20

19 Adaxial surface of the glumes smooth (no papillae); adaxial blade surface on average with 1 prominent rib every 4 or with 3 types of ribs: prominent, slightly prominent and thin

$\times$ Thinoelymus mucronatus

- Adaxial surface of the glumes, at least in the middle, more or less papillose; adaxial blade surface on average with 1 prominent rib every 2

Thinopyrum intermedium subsp.

intermedium $\times$ Elymus campestris subsp. campestris

20 Glumes lanceolate, gradually narrowed at the apex into an awn to $1 \mathrm{~mm}$ long; adaxial blade surface with prominent ribs rounded at the top .......... 21

- Glumes ovate-lanceolate to oblong-lanceolate, apiculate to mucronate or awned; adaxial blade surface with prominent ribs flattened or truncate at the top ................................................ 22

21 Internodes of the rachis 4-6(-8) $\mathrm{mm}$; spikelets 3-5-flowered; glumes 5-6-veined; leaves and culms slightly glaucous; blades near the ligula adaxially and abaxially glabrous; free margins of sheaths sparsely ciliolate to glabrous

Elytrigia aenaeana Internodes of the rachis $6-10(-12) \mathrm{mm}$; spikelets 5-7-flowered; glumes 5-8-veined; leaves and culms strongly glaucous to glaucous-green; blades near the ligula adaxially and abaxially puberulous; free margins of sheaths glabrous ........... Elytrigia laxula

22 Adaxial surface of the glumes, at least in the middle, more or less papillose .............................. Elymus campestris subsp. campestris $\times$ Elymus repens Adaxial surface of the glumes without papillae .. $\times$ Thinoelymus drucei

\section{REFERENCES}

Ardenghi N. M. G. \& Polani F., 2016 - La flora della provincia di Pavia (Lombardia, Italia settentrionale). 1. L'Oltrepò Pavese. Nat. Hist. Sci. Atti Soc. it. Sci. nat. Museo civ. Stor. nat. Milano, 3 (2): 51-79.

Arrigoni P. V., 2015 - Flora dell'isola di Sardegna 6. Carlo Delfino, Sassari. 
Barchieri G. \& Ardenghi N. M. G., 2013 - Notula 1960. Elytrigia obtusiflora (DC.) Tzvelev subsp. obtusiflora (Poaceae). Inf. Bot. Ital., 45 (1): 93. 2013.

Bartolucci F., Peruzzi L., Galasso G., Albano A., Alessandrini A., Ardenghi n. m. g., Astuti G., Bacchetta G., Ballelli S., Banfi E., Barberis G., Bernardo L., Bouvet D., Bovio M., Cecchi L., Di Pietro R., Domina G., Fascetti S., Fenu G., Festi F., Foggi B., Gallo L., Gottschlich G., Gubellini L., Iamonico D., Iberite M., Jiménez-Mejías P., Lattanzi E., Marchetti D., Martinetto E., Masin R. R., Medagli M., Passalacqua N. G., Peccenini S., Pennesi R., Pierini B., Poldini L., Prosser F., Raimondo F. M., RomaMarzio F., Rosati L., Santangelo A., Scoppola A., Scortegagna S., Selvaggi A., Selvi F., Soldano A., Stinca A., Wagensommer R. P., Wilhalm T., \& Conti F., 2018 - An updated checklist of the vascular flora native to Italy. Pl. Biosystems 2018. <DOI: https// doi.org/10.1080/11263504.2017.1419996>

Baum B. R. \& Johnson D. A., 2017 - Lophopyrum Á.Löve (1980), Thinopyrum, Á.Löve (1980), Trichopyrum Á.Löve (1986): one, two or three genera? A study based on the nuclear 5S DNA. Genet. Resour. Crop Evol. <DOI 10.1007/s10722-0170519-z>

Boissier P. E. \& Heldreich T. H. H. von, 1859 - Diagnoses Plantarum Orientalium Novarum, ser. 2 4: 142.

Bowden W. M., 1965. Cytotaxonomy of the species and interspecific hybrids of the genus Agropyron in Canada and neighbouring areas. Can. J. Bot., 43: 1421-1448.

Chen Q., Conner R. L., LarocheA. \& Thomas J. B., $1998-$ Genome analysis of Thinopyrum intermedium and Thinopyrum ponticum using genome in situ hybridization. Genome, 41 (4): 580-586.

Dewey D. R., 1984 - The genomic system of classification as a guide to intergeneric hybridization with the perennial Triticeae. In: Gene manipulation in plant improvement: 209-279. Proceedings of the $16^{\text {th }}$ Stadler Genetics Symposium. Gustafson J. P. (ed.). Plenum Publishing Company, New York.

Dizkirici A., Kaya Z., Cabı E. \& Doğan M., 2010 Phylogenetic relationships of Elymus L. and related genera (Poaceae) based on the nuclear ribosomal internal transcribed spacer sequences. Turk. J. Bot., 34 (2010): 467-478.

Dong Z., Fan X., Sha L., Wang Y., Zeng J., Kang H., Zhang H., Wang X., Zhang L., Ding C., Yang R. \& Zhou Y., 2015 - Phylogeny and differentiation of the St genome in Elymus L. sensu lato (Triticeae; Poaceae) based on one nuclear DNA and two chloroplast genes. BMC Plant Biol., (2015): 15. <DOI: 10.1186/s12870-015-0517-2>

Fan X., Sha L., Dong Z., Zhang H., Kang H., Wang Y., Wang X., Zhang L., Ding C., Yang R., Zheng Y. \& Zhou Y., 2013 - Phylogenetic relationships and Y genome origin in Elymus L. sensu lato (Triticeae; Poaceae) based on single-copy nuclear Accl and
Pgkl gene sequences. Molec. Phylogen. Evol., 69 (3): 919-928.

Galasso G., Conti F., Peruzzi L., Ardenghi N. M. G., Banfi E., Celesti-Grapow L., Albano A., Alessandrini A., Bacchetta G., Ballelli S., Bandini Mazzanti M., Barberis G., Bernardo L., Bouvet D., Bovio M., Cecchi L., Del Guacchio E., Domina G., Fascetti S., Gallo L., Gubellini L., Guiggi A., Iamonico D., Iberite M., Jiménes Mejías P., Lattanzi E., Marchetti D., Martinetto E., Masin R. R., Medagli P., Passalacqua N. G., Peccenini S., Pennesi R., Pierini B., Podda L., Poldini L., Prosser F., Raimondo F. M., Roma Marzio F., Rosati L., Santangelo A., Scoppola A., Scortegagna S., Selvaggi A., Selvi F., Soldano A., Stinca A., Wagensommer R. P., Wilhalm T. \& Bartolucci F., 2018 - An updated checklist of the vascular flora alien to Italy. Pl. Biosystems 2018. <DOI: https//doi.org/10.1080/11263504.2018.1441 197>

Gao G., Tang Z., Deng J., Gou X., Wang Q., Zhang Y., Ding C., Zhang L., Zhou Y. \& Yang R., 2016. Phylogenetic relationships and $\mathrm{Y}$ genome origin in Kengyilia (Triticeae: Poaceae) based on single copy gene DMC1. Biologia, 71 (3): 298-304. <DOI: 10.1515/biolog-2016-0041>

Hohla M. \& Scholz H., 2011 - Zwei neue indigene Elytrigia-Arten (Poaceae) der Flora Mitteleuropas. Stapfia, 95 (2011): 46-54.

Jarvie J. K., 1992 - Taxonomy of Elytrigia sect. Caespitosae and sect. Junceae (Gramineae: Triticeae). Nord. J. Bot., 12 (2): 155-169.

Löve A., 1984 - Conspectus of the Triticeae, Feddes Repert., 95: 425-521.

Mason-Gamer R. J., 2013 - Phylogeny of a genomically diverse group of Elymus (Poaceae) allopolyploids reveals multiple levels of reticulation. Aliso, 23 (1): 372-379.

Melderis A., 1980 - Elymus. In: Flora Europaea Tutin T. G., Heywood V. H., Burges N. A., Moore D. M., Valentine D. H., Walters S. M. \& Webb D. A. (eds.). Cambridge Univ. Press., 5: 192-198.

Mizianty M., Frey L. \& Szczepaniak M., 2001 - The Agropyron-Elymus complex (Poaceae) in Poland: biosystematics. In: Studies on grasses in Poland. Frey L. (ed.). W. Szafer Institute of Botany, Polish Academy of Sciences, Krakow, 25-77.

Pignatti S., 2017 - Flora d'Italia 1. Edagricole, Bologna.

Pignatti S., 1982 - Flora d'Italia 3. Edagricole, Bologna.

Rottensteiner W. K., 2014 - Exkursionsflora für Istrien. Verlag der Naturwissenschaftlichen Vereins für Kärnten, Klagenfurt.

Rottensteiner W. K., 2017 - Notizen zur "Flora von Istrien", Teil III. Joannea Botanik, 14: 145-260.

Soreng R. J., Peterson P. M., Romaschenko K., Davidse G., Teisher J. K., Clark L. G., Barberá P., Gillespie L. J. \& Zuloaga F. O., 2017 - A worlwide phylogenetic classification of the Poaceae (Gramineae) II: An update and a comparison of two 2015 classifications. J. Syst. Evol., 55 (4): 259-290. 
Stace C. A., 2001 - The interspecific hybrids of the rhizomatous couches, Elytrigia Desv. (Poaceae). Watsonia, 23: 543-551.

Thiébaud M.-A., 1987 - Contribution à l'étude des espèces littorales du genre Elymus L. Candollea, 42 (1): 327-350.

Tison J.-M. \& de Foucault B. (coords.), 2014 - Flora Gallica. Flore de France. Biotope, Mèze.

Valdés B. \& Scholz H., 2006 - The Euro+Med treatment of Gramineae. A generic synopsis and some new names.Willdenowia, 36 (2): 657-669. 